\title{
Commentary: A rare intracaval mass with intracardiac extension: A value of frozen section revisited?
}

\author{
Yaroslav Y. Ivanov, MD, PhD, ${ }^{a}$ and Igor E. Konstantinov, MD, PhD, FRACS ${ }^{\mathrm{a}, \mathrm{b}, \mathrm{c}, \mathrm{d}}$
}

\footnotetext{
From the a'Royal Children's Hospital, Melbourne, Australia; ${ }^{b}$ Murdoch Children's Research Institute, Melbourne, Australia; ${ }^{\mathrm{C}}$ University of Melbourne, Melbourne, Australia; and ${ }^{\mathrm{d}}$ Melbourne Children's Centre for Cardiovascular Genomics and Regenerative Medicine, Melbourne, Australia.

Disclosures: Authors have nothing to disclose with regard to commercial support.

Received for publication April 30, 2019; accepted for publication May 1, 2019; available ahead of print June 27 , 2019.

Address for reprints: Igor E. Konstantinov, MD, PhD, FRACS, Royal Children's Hospital, Flemington Rd, Parkville, VIC 3052, Australia (E-mail: igor.konstantinov@ rch.org.au).

J Thorac Cardiovasc Surg 2019;158:e103-4

$0022-5223 / \$ 36.00$

Crown Copyright (C) 2019 Published by Elsevier Inc. on behalf of The American Association for Thoracic Surgery https://doi.org/10.1016/j.jtcvs.2019.05.009
}

The most common types of intracardiac masses are myxomas, metastatic tumors, vegetations, and thrombi. Aberrant hepatic tissue (AHT) is a rare abnormality typically found in the abdominal cavity ${ }^{1}$ and sometimes in the thoracic cavity. AHT has been classified as an accessory when connection to the liver parenchyma is maintained or ectopic when no such connection is evident. ${ }^{2}$ In exceptionally rare cases, AHT can be found within the heart chambers and almost always in the right atrium (RA). The incidence of AHT presenting as an RA mass is limited to only a few case reports. In the majority of them, AHT was accidentally found in the RA mimicking the clinical course of atrial myxoma. ${ }^{2-5}$

There is no uniform theory explaining the incidence of AHT within the heart chambers. Clearly, there has to be a hematogenous spread of hepatic cells with regenerative potential to the heart chambers, and in the absence of trauma, the embryological explanation of this phenomenon is the most attractive. ${ }^{6}$ Embryogenesis of the heart and the liver occurs during the same period of development between the fifth and eighth weeks (Figure 1). The 2 developing organs will become separated only by the septum transversum (Figure $1, A$ ), which will eventually develop into the diaphragm (Figure $1, B$ ). More specifically, because of the close proximity of the caudate liver lobe to the inferior vena cava (IVC), during embryogenesis these regenerative hepatic cells have the potential to move to the IVC and then further to other areas of the body, including the heart chambers (Figure 1, C). ${ }^{6,7}$ The accessory hepatic cells develop into ectopic hepatic tissue or, if they still remain connected to the liver, to the accessory hepatic lobe (AHL). Perhaps the predominant incidence of AHT in the adult population suggests that once regenerative hepatic cells seed the heart chambers, they rest within them for a period of time, and then some unknown stimuli could initiate established.

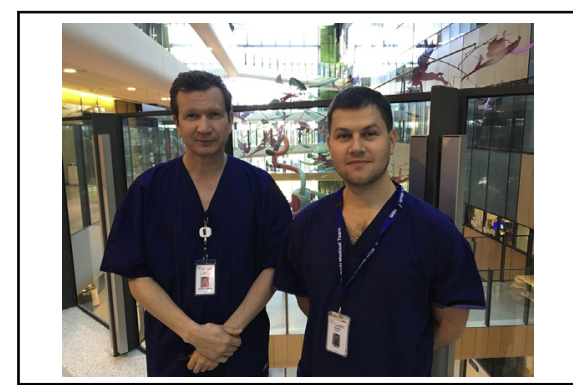

Igor E. Konstantinov, MD, PhD, FRACS, and Yaroslav Y. Ivanov, MD, PhD

Central Message

Aberrant hepatic tissues is a rare finding in the right atrial mass.

See Article page e101.

their growth. Moody and colleagues ${ }^{2}$ observed de novo AHT formation in the RA mimicking RA myxoma in a patient who did not have any evidence of any intracardiac mass 18 months before the definitive diagnosis was

Surgical treatment of cardiac tumors located close to the IVC is not always straightforward and in some instances requires unusual solutions. ${ }^{8}$ In this issue of the Journal, D'Angelo and colleagues ${ }^{9}$ report a successful application of deep hypothermic circulatory arrest (DHCA) for resection of AHL in the RA, which initially was thought to be an RA myxoma. A similar approach with the use of DHCA for the resection of AHL has been reported by Forest and colleagues. ${ }^{4}$ Use of DHCA seems to be a logical and valuable option providing a blood-free surgical field in the area of the RA-IVC junction, which helps to delineate the entire anatomy of the AHL. On the other hand, femoral cannulation, with the IVC cannula positioned just inferior to the retro-hepatic IVC, may provide sufficient IVC drainage to accomplish AHL resection without DHCA. ${ }^{3,5}$ Furthermore, a frozen section assessment, during which the normal heart function is restored and bypass is discontinued, could be helpful in some patients with a similar location of the RA mass to avoid extensive resection and reconstruction of the IVC wall in patients with a benign non-neoplastic lesion. 

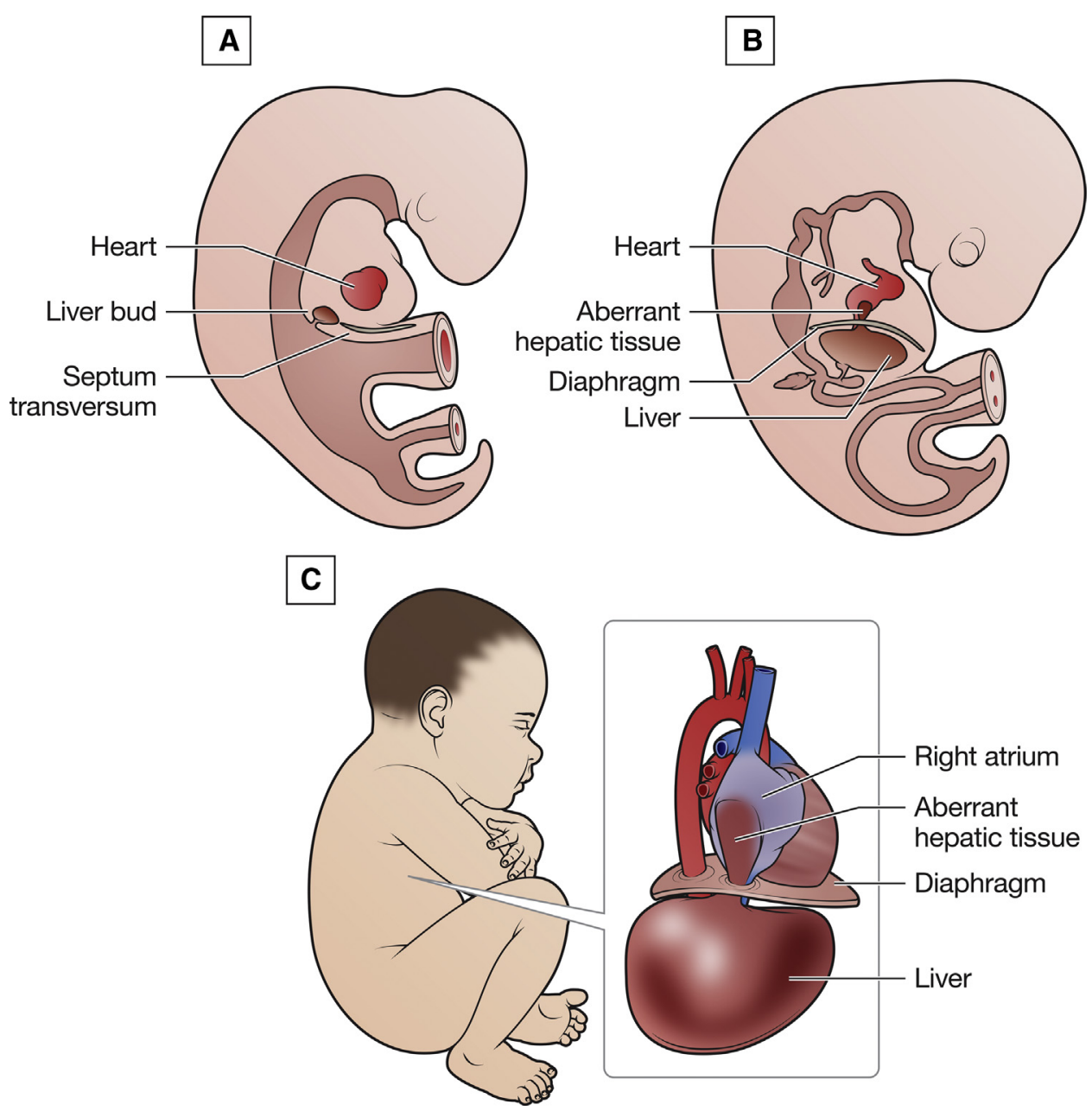

FIGURE 1. Development of heart, liver, septum transversum (A), and aberrant hepatic tissue (B, C).

\section{References}

1. Wang C, Cheng L, Zhang Z, Xie T, Ding H, Deng Q, et al. Accessory lobes of the liver: a report of 3 cases and review of the literature. Intractable Rare Dis Res. 2012;1:86-91.

2. Moody WE, Hübscher SG, Rooney SJ, Doshi SN. Intracardiac ectopic liver mimicking atrial myxoma-an unusual cause for a right atrial mass. Int J Cardiol. 2016:209:210-2.

3. Trocciola SM, Balsam LB, Yee H, Gianos E, Srichai MB, DeAnda A. Ectopic liver: an unexpected finding in a right atrial mass. Ann Thorac Surg. 2011;92: 715-8.

4. Forest SJ, Kaplan KC, Michler RE. Accessory liver in the right atrium: a rare cause of syncope. Ann Thorac Surg. 2016;102:e229-31.
5. Yeh B, Hudson AJ, Reoma JL, Popa C, Andersen J, Lichtenberger J. Intracardiac heterotopic liver presenting as a right atrial myxoma: a case report. Mil Med. 2018; 183:e175-8.

6. Xu L, Jeudy J, Burke AP. Ectopic hepatic tissue presenting as right atrial mass. Hum Pathol. 2012;43:958-60.

7. Peake B, Seevanayagam S, Vazquez M, Weinberg L. Aberrant non-neoplastic liver tissue presenting as an intra-atrial mass. BMJ Case Rep. 2017. bcr2017219463.

8. Konstantinov IE, Saxena P, Barrett T, Jenkins G. Resection and reconstruction of the roof of the coronary sinus for an unusually attached left atrial myxoma. $J$ Thorac Cardiovasc Surg. 2009;137:1032-4.

9. D'Angelo AM, van Boxtel BS, Wu IY, Smith CR. Deep hypothermic circulatory arrest for resection of a right atrial accessory hepatic lobe. J Thorac Cardiovasc Surg. 2019;158:e101-2. 